\title{
PERBANDINGAN ANALISIS PENERAPAN PRINSIP BANK SYARIAH MENURUT UNDANG-UNDANG NO.21 TAHUN 2008 DENGAN ANALISIS BANK KONVENSIONAL UNDANG-UNDANG NO.10 TAHUN 1998
}

\author{
Devi Fitria Wulandari 1, Ernawati Suwarno ${ }^{2,}$ Yusni Nuryani ${ }^{3}$ \\ Fakultas Ekonomi, Universitas Pamulang \\ Email: dosen02529@unpam.ac.id ${ }^{1}$,dosen02533@unpam.ac.id2, \\ dosen02458@unpam.ac.id ${ }^{3}$,
}

\begin{abstract}
Purpose. Application of Islamic Bank Analysis according to Law No. 21 of 2008 with a comparison of Conventional Banks of this study is to determine the application and analysis of Islamic banks and conventional banks: Indonesia is the country with the largest number. Muslims in the world, but all the values of the application of sharia in daily life are not yet perfect.
\end{abstract}

Methods. literature / literature can be in the form of studies: the holy book Al Qur 'an or Al Hadith, scientific books, laws and regulations.

Findings. Moving on from what is explained above, it is clear that the financial system plays a very important role in the economy when it comes to channeling funds from those who have (surplus funds) to those who need funds, if the financial system does not work well, the economy will not come. efficient and expected economic growth will not be achieved. This research is descriptive in nature, meaning that this research provides a description or description of a situation as clearly as possible without any treatment of the object under study. Banking institutions are at the core of financial institutions that make up a place for moving entities, and even government agencies to deposit their funds. The main step that must be done is to open the concept of funding that allows it to be done only with procedures and still do it with care. Reforms related to funding is to improve the quality of the funding system better. The real step is to avoid fudhul trade transactions and give priority to funding for real sectors that offer job opportunities and reduce poverty. Investors who place their funds will get a reward from the bank in the form of profit sharing or other forms approved by the Islamic Islamic sharia bank to the parties who need parties in general in the sale and purchase contract and cooperation. Obtained in profit margins, profit sharing forms and / or other forms in accordance with Islamic sharia. Implementation of a conventional bank risk and return system according to Law no. 10 of 1998 is the amount of losses that are estimated (to be estimated) to be borne by the company.

Implication. As for the implementation of the Islamic banking system according to Law no. 21 of 2008 is the risk and return provided by Islamic banks to investors calculated using a profit sharing system so that it is fair for both parties, from the side of third fund collectors if Islamic banks earn large income, investor customers will also receive large profit sharing. And vice versa if the results obtained by customers are small, the Islamic bank is also small.

Keywords. Application of Islamic Bank Analysis, Application of Conventional Bank Analysis, Funding 


\begin{abstract}
ABSTRAK
Tujuan. Penerapan Analisis Bank Syariah menurut Undang-Undang Nomor 21 Tahun 2008 dengan perbandingan Bank Konvensional penelitian ini untuk mengetahui penerapan dan analisis bank syariah dan bank konvensional: Indonesia merupakan negara dengan jumlah terbesar. Umat Islam di dunia, tetapi semua nilai penerapan syariah dalam kehidupan sehari-hari belumlah sempurna.
\end{abstract}

Metode. literatur / literatur dapat berupa kajian: kitab suci Al Qur 'an atau Al Hadits, kitab ilmiah, peraturan perundang-undangan.

Hasil. Beranjak dari penjelasan di atas, terlihat jelas bahwa sistem keuangan memegang peranan yang sangat penting dalam perekonomian dalam hal penyaluran dana dari pihak yang memiliki (dana berlebih) kepada pihak yang membutuhkan dana, apabila sistem keuangan tidak berjalan. yah, ekonomi tidak akan datang. pertumbuhan ekonomi yang efisien dan diharapkan tidak akan tercapai. Penelitian ini bersifat deskriptif, artinya penelitian ini memberikan gambaran atau gambaran suatu keadaan sejelas mungkin tanpa ada perlakuan terhadap objek yang diteliti. Lembaga perbankan merupakan inti dari lembaga keuangan yang menjadi tempat bagi entitas yang bergerak, bahkan lembaga pemerintah untuk menyimpan dananya. Langkah utama yang harus dilakukan adalah membuka konsep pendanaan yang memungkinkan dilakukan hanya dengan prosedur dan tetap dilakukan dengan hati-hati. Reformasi terkait pendanaan adalah dengan meningkatkan kualitas sistem pendanaan yang lebih baik. Langkah sebenarnya adalah menghindari transaksi perdagangan fudhul dan mengutamakan pendanaan untuk sektor riil yang menawarkan lapangan kerja dan mengentaskan kemiskinan. Investor yang menempatkan dananya akan mendapatkan reward dari bank berupa bagi hasil atau bentuk lain yang disetujui oleh bank syariah syariah kepada pihak yang membutuhkan pihak-pihak pada umumnya dalam akad jual beli dan kerjasama. Diperoleh dalam bentuk margin keuntungan, bentuk bagi hasil dan / atau bentuk lain yang sesuai dengan syariah Islam. Penerapan sistem risiko dan pengembalian bank konvensional menurut UU No. 10 Tahun 1998 adalah besarnya kerugian yang diperkirakan (akan diperkirakan) yang akan ditanggung oleh perusahaan.

Implikasi. Adapun implementasi sistem perbankan syariah menurut UU No. 21 Tahun 2008 adalah resiko dan pengembalian yang diberikan bank syariah kepada investor dihitung dengan menggunakan sistem bagi hasil sehingga adil bagi kedua belah pihak, dari sisi penghimpun dana ketiga jika bank syariah memperoleh pendapatan besar maka nasabah investor juga akan mendapat untung besar. berbagi. Begitu pula sebaliknya jika hasil yang diperoleh nasabah kecil maka bank syariah juga kecil.

Kata Kunci. Penerapan Analisis Bank Syariah, Penerapan Analisis Bank Konvensional, Pendanaan.

\title{
1. Pendahuluan
}

Manajemen sumber daya manusia mengganggap bahwa karyawan adalah kekayaan utama sebuah organisasi atau perusahaan yang harus dikelola dengan baik karena keberadaan manajemen sumber daya manusia sangat penting dalam mengelola, mengatur, dan mengurus sebuah perusahaan. Peranan sumber daya (tenaga kerja) yang dimiliki oleh individu dapat digunakan secara maksimal sehingga tercapai tujuan bersama perusahaan. Setiap perusahaan berupaya untuk memiliki karyawan yang berperan aktif sehingga dapat menghasilkan produktivitas yang baik dan memberikan kontribusi pada pencapaian target yang telah ditetapkan oleh perusahaan. Perkembangan penggunaan batubara didunia sebagai energi 
dimulai sejak revolusi industri di Eropa (abad 19), yaitu untuk menggerakkan lokomotif dan mesin-mesin uap sehingga disebut zaman keemasan batubara.

Batubara bahan bakar fosil adalah sumber energi terpenting untuk pembangkitan listrik dan berfungsi sebagai bahan bakar. Begitu halnya dengan PT Hadi Prima Teknik anak cabang dari PT. Sadikun Niagamas Raya Perusahaan yang bergerak dibidang batubara ini dikembangkan untuk memperluas jaringan, menjangkau pasar-pasar potensial serta kesiapan dalam menghadapi era globalisasi. PT HADI PRIMA TEKNIK menjadi trader penjualan produk batu bara, jalur PT Hadi Prima Teknik mencakup skala nasional dan diorganisir melalui bisnis Sektor perbankan sangat memerlukan adanya disribusi risiko yang efisien sebagai salah satu pilar sektor keuangan dalam melaksanakan fungsi intermediasi dan pelayanan jasa keuangan. Tingkat efisiensi dalam distribusi risiko inilah yang nantinya menentukan alokasi sumberdaya dana di dalam perekonomian. Oleh karena itu, pelaku sektor perbankan, dan bank syariah khususnya di tuntut untuk mampu secara efektif mengelola risiko yang dihadapinya. Penerapan sistem manajemen risiko pada perbankan sangat diperlukan.

Baik untuk menekan kemungkinan terjadinya kerugian akibat risiko maupun memperkuat struktur kelembagaan, misalnya kecukupan modal untuk meningkatkan kapasitas, posisi tawar menawar dan reputasinya dalam menarik nasabah. Kewajiban penerapan manajemen risiko oleh Bank Indonesia (BI) yang disusul oleh ketentuan kecukupan modal dan menambah beban perhitungannya yang dinilai sejauh ini cukup kompleks, telah memberikan kontribusi penting bagi kelangsungan usaha perbankan nasional.

Manajemen risiko sangat penting bagi stabilitas perbankan, hal ini karena bisnis perbankan sangat berhubungan dengan risiko. Dalam kegiatannya, baik menghadapi berbagai risiko, seperti risiko kredit (pembiayaan), risiko pasar dan risiko operasional. Manajemen risiko yang baik bagi bank bisa memastikan bank akan selamat dari kehancuran jika keadaan terburuk terjadi. Risiko yang ada akan dihadapi perbankan dalam pengelolaan usaha dalam mendapatkan keuntungan.

Adanya persaingan antar bank syariah maupun dengan bank konvensional, membuat bank syariah dituntut untuk memiliki kinerja yang bagus agar dapat bersaing dalam memperebutkan pasar perbankan nasional di Indonesia. Selain itu Bank Indonesia (BI) juga semakin memperketat dalam pengaturan dan pengawasan perbankan nasional. Karena Bank Indonesia (BI) tidak mengulangi peristiwa di awal krisis ekonomi pada tahun 1997 dimana banyak bank dilikuidasi karena kinerjanya tidak sehat, yang pada akhirnya merugikan masyarakat. Bank syariah yang muncul di tengah-tengah mayoritas penduduk Imdonesia yang merupakan muslim karena membutuhkan adanya suatu sistem perekonomian yang menerapkan hukum islam secara menyeluruh di semua sektor kehidupan. Sistem perekonomian yang diinginkan oleh sebagian besar masyarakat muslim di Indonesia adalah berbasis syariah (berlandaskan Al Qur'an). Oleh karena itu, Majelis Ulama Indonesia (MUI) sebagai pembimbing dan pelayan umat (Ra'iy wa khadim al ummah) mengupayakan adanya perekonomian yang sesuai dengan prinsip Islam yaitu perbankan syariah yang sekarang marak keberadaannya. Bahkan, bank konvensional pun sekarang menyediakan basis syariahnya.

Dalam islam, investasi ditentukan oleh beberapa variabel diantaranya adalah ekspektasi keuntungan pada sebuah projek, pendapatan dan kondisi perekonomian (bukan oleh tingkat bunga yang selama ini dikenal dalam teori ekonomi konvension). Keputusan investasi bagi seorang investor menyangkut masa akan datang yang mengandung ketidakpastian, yang berarti mengandungunsur risiko bagi investor, pengetahuan tentang risiko merupakan suatu hal yang penting dimiliki oleh setiap investor maupun calon investor. 
Dalam pandangan Islam, investasi dasar yang perlu diketahui dalam perbankan syariah yang termasuk produk penghimpun dana (finding adalah deposito).Berdasarkan Undang-Undang Nomor 10 Tahun 1998 tentang Perubahan atas Undang-Undang Nomor 7 Tahun 1992 tentang perbankan, yang dimaksud dengan deposito berjangka adalah simpanan yang penarikannya hanya dapat dilakukan pada waktu-waktu tertentu menurut perjanjian antara penyimpanan dengan bank yang bersangkutan. Adapun yang dimaksud dengan deposito syariah adalah deposito yang dijalankan berdasarkan prinsip syariah. Dalam hal ini, Dewan Syariah Nasional (DSN) telah mengeluarkan fatwa yang menyatakan bahwa deposito yang dibenarkan adalah deposito yang berdasarkan prinsip mudharabah.

"Perbedaan antara bank konvensional dan bank syariah terletak pada filosofi atau ajaran yang mendasarinya. Bank konvensional dibangun dari praktik ekonomi kapitalisme yang menganut faham liberalisme, yang berpatokan pada perhitungan utilitas sehingga manusianya lebih cenderung menjadi homo economicus." (Hendy Herijanto, 2013:81)

Statistik Perbankan Indonesia (SPI) merupakan media publikasi yang menyajikan data mengenai perbankan Indonesia. SPI diterbitkan secara bulanan oleh Departemen Perizinan dan Informasi, untuk memberikan gambaran perkembangan perbankan di Indonesia.

Menurut Paul L. Krugman dan Maurice Obstfeld bahwa pada kenyataanya, seorang investor yang netral terhadap resiko cenderung mengambil posisi agresif maksimum. Ia akan membeli sebanyak mungkin aset yang menjanjikan hasil tinggi dan menjual sebanyak mungkin aset yang hasilnya lebih rendah.

Menurut Dr. Insunkindro, dalam bukunya ekonomi Uang dan Bank, sistem keuangan (financial system) pada umumnya merupakan suatu kesatuan sistem yang dibentuk dari semua lembaga keuangan yang ada dan yang kegiatan utamanya dibidang keuangan adalah menarik dana dari dan memyalurkannya kepada masyarakat. Munir Fuady merumuskan hukum perbankan adalah seperangkat kaidah hukum dalam bentuk peraturan Perundangundangan, yurisprudensi, doktrin, dan lain-lain.

Dari latar belakang masalah di atas, maka penulis mengindentifikasikan beberapa masalah sebagai berikut:

1) Yang menjadi Penerapan Analisis Bank Syariah menurut Undang - Undang No. 21 Tahun 2008 dengan perbandingan Bank Konvensional.

2) Yang menjadi risiko dan tingkat dan pengembalian pada perbankan syariah UndangUndang No. 21 Tahun 2008.

Berkaitan dengan hal tersebut, penelitian ini dilakukan untuk meneliti lebih lanjut tentang "Perbandingan Analisis Penerapan Prinsip Bank Syariah Menurut UndangUndang No.21 Tahun 2008 Dengan Analisis Bank Konvensional Undang-Undang No.10 Tahun 1998"

\section{Kajian Pustaka}

Teori dipergunakan untuk menerangkan atau menjelaskan mengapa gejala spesifik atau proses tertentu terjadi, Sedangkan kerangka teori merupakan landasan cari teori atau dukungan teori dalam membangun atau dukungan teori dalam membangun atau memperkuat kebenaran dari permasalahan, kerangka teori ini dimaksud adalah kerangka pemikiran atau butir - butir pendapat teori, sebagai pegangan baik disetujui atau tidak disetujui.

Dalam sebuah penelitian ini adalah hal yang sangat penting, karena akan dimuat teoriteori yang relevan. Kerangka teori merupakan kerangka pemikiran atau butir-butir pendapat, teori, tesis mengenai sesuatu kasus atau permasalahan (problem), yang menjadi bahan perbandingan, pegangan teoritis yang mungkin disetujui. 5Pada penelitian tesis ini yang digunakan adalah sebagai berikut: 
Grand Theory. Grand Theory yang digunakan dalam tesis ini mengkaji resktrukturisasi kebijkan pembiayaan bagi bank syariah dan usaha syariah ini digunakan teori resktruturisasi sebagai grand theory, atau disebut juga dengan teori sebagai pisau analisis. Restrukturisasi merupakan tindakan berani dengan melakukan pengorbanan. Harapannya, nilai perusahaan secara fundamental membaik. Dalam era persaingan yang semakin ketat, setiap kali sebuah perusahaan harus mengevaluasi kinerjanya, serta melakukan serangkaian perbaikan, agar tetap tumbuh dan dapat bersaing. Perbaikan ini akan dilaksanakan secara terus menerus, sehingga kinerja perusahaan makin baik dan dapat terus unggul dalam persaingan atau minimal tetap dapat bertahan. Salah satu strategi untuk memperbaiki dan memaksimalkan kinerja.

Restruktrur $\mathrm{m} 1$ dalam hukum perusahaan bertujuan untuk memperbaiki dan memaksimalisasi kinerrja perusahaan. Perusahaan melakukan pembenahan supaya segera lepas dari krisis melalui berbagai aspek perusahaan, mulai dari perbaikan portofolio perusahaan, perbaikan permodalan, perampmgan manajemen, perbaikan sistem, pengelolaan perusahaan sampai pada perbaikan sumber daya manusia.Dengan demikian, restruktur perusahaan merupakan kepentingan semua pihak. Bukan saja pihak manajemen, namun juga merupakan kepentingan komisaris yang mewakili kepentingan pemegang saham.

Hal ini berkaitan erat dengan penyelamatan kredit melalui jalur non hukum. Restrukturisasi merupakan upaya yang dilakukan bank dalam rangka membantu nasabah agar dapat menyelesaikan kewajibannya, antara lain melalui (Iswi Haryani, 2010:46) ::

1) Penjadwalan kembali (rescheduling), yaitu perubahan jadwal pembayaran kewajiban nasabah atau jangka waktunya, Penjadwalan kembali dapat dilakukan dengan cara tindakan rescheduling diberikan kepada debitur yang masih menunjukan itikad baik utnuk melunasi kewajibannya. Tindakan ini dilakukan karena terjadi kelebihan pembiayaan terhadap obyek kredit (over finance).

2) Persyaratan kembali (reconditioning), yaitu perubahan sebagian atau seluruh persyaratan pembiayaan, antara lain perubahan jadwal pembayaran, jumlah angsuran, jangka waktu dan/atau pemberian potongan sepanjang tidak menambah sisa kewajiban nasabah yang harus dibayarkan kepada bank. Tindakan Reconditioning dapat diberikan kepada debitur yang masih memilki itikad baik untuk melunasi kewajibannya, berdasarkan pembuktian secara kuantitatif merupakan alternatif yang terbaik.

3) Penataan kembali (resctructuring), yaitu perubahan persyaratan pembiayaan tidak terbatas pada rescheduling atau reconditioning. Restrukturisasi kredit hanaya dapat dilakukan untuk kredit dengan kualitas, kurang lancar, diragukan dan macet.

Middle Theory. Middle Theory yang digunakan dalam perbandingan ini adalah Teori Pendukung atau dikenal dengan teori sebagai wacana, pada penelitian ini menggunakan Teori tentang Kesehatan Bank. Kesehatan terhadap suatu lembaga keuangan merupakan kepentingan semua pihak yang terkait, baik itu pemilik modal dan pengelola bank, masyarakat yang menggunakan jasa bank, maupun Otoritas Jasa Keuangan (OJK) selaku pemilik otoritas dalam mengawasi bank. (Totok Budisantoso dan Sigit Triandani, 2014:22-23). Budi Santoso dan Triandaru mengartikan kesehatan bank sebagai "Kemampuan suatu bank untuk melakukan kegiatan operasional Perbankan secara normal dan mampu memenuhi semua kewajibannya dengan baik dengan cara-cara yang sesuai dengan peraturan yang berlaku. (Agnes Sawir, 2005:2). Menurut Dr. Insukindro dalam bukunya, Ekonomi Uang dan Bank, sistem keuangan (financial system) pada umumnya merupakan suatu kesatuan sistem yang dibentuk dari semua lembaga keuangan yang ada dan yang kegiatan utamanya di bidang keuangan adalah menarik dana dari dan menyalurkanya kepada masyarakat.

\section{Metode Penelitian}

Metode Pengumpulan Data. Untuk memperoleh bahan-bahan hukum primer, sekunder dan tertier teknik pemngumpulan data yang dilakukan adalah melalui penelitian kepustakaan (Library Research). Jenis penelitian kepustakaan/literatur bisa berupa kajian : kitab suci Al Qur' an atau Al Hadits, buku ilmiah, peraturan perundang-undangan. Studi 
kepustakaan merupakan suatu kegiatan yang tidak dapat dipisahkan dari suatu penelitian. Teori-teori yang mendasari masalah dan bidang yang akan diteliti dapat ditemukan dengan melakukan studi kepustakaan.

Dengan melakukan studi kepustakaan, peneliti dapat memanfaatkan semua informasi dan pemikiran-pemikiran yang relevan denan penelitiannya.untuk melakukan studi kepustakaan, perpustakaan merupakan suatu tempat yang tepat guna memperoleh bahanbahan dan informasi yang relevan untuk dikumpulkan, dibaca, dikaji, dicatat dan dimanfaatkan. Setelah menemukan masalah yang akan diteliti maka seorang peneliti akan melakukan kegiatan-kegiatan yang berkaitan dengan penelitiannya.

Salah satu diantaranya adalah melakukan studi kepustakaan, yang mungkin sudah dirintisnya ketika masih dalam tahap mencari masalah yang diteliti, hampir semua penelitian memerlukan studi pustaka. Walaupun orang sering membedakan antara riset kepustkaan dan riset lapangan, keduanya tetap memerlukan penelusuran pustaka. Perbedaan utamanya hanyalah terletak pada fungsi, tujuan dan atau kedudukan studi pustaka dalam masing-masing riset tersebut, dalam riset pustaka, penelusuran pustaka lebih daripada sekedar melayani fungsi-fungsi persiapan kerangka teori mempertajam metodelogi atau memperdalam kajain teoritis.

Riset pustaka dapat sekaligus memanfaatkan sumber perpustakaan untuk memperoleh data penelitian tanpa melakukan riset lapangan. Idealnya sebuah riset profesional menggunakan kombinasi riset pustaka dan lapangan dengan penekanan pada salah satu diantaranya, Dalam tulisan ini akan dibahas apa yang dimaksud dengan studi kepustakaan, tujuan, sumber-sumber, hambatan, dan bagaimana melakukan studi kepustakaan. Studi pustaka dilakukan sebelum peneliti memulai penelitiannya.

\section{Hasil Penelitian dan Pembahasan}

Bank syariah menggunakan istilah bagi hasil untuk produk yang dimilikinya, sedangkan bank konvensional menggunakan isitilah bunga. Pada dasamya keduamya sama, yang membedakan pada persentase atau besar bunga yang digunakan serta potongan yang diberlakukan. Besaran bunga pada bank syariah tidak sebesar bank konvensional. Potongan Pada kedua bank juga berbeda, pada bank konvensional pinjaman akan dipotong untuk biaya adminitrasi sedangkan pada bank syariah akan dimasukan ke tabungan.

Penelitian ini menjelaskan bahwa unsur bunga ada karena terdapat beberapa hal yang tidak dapat dilakukan oleh syariah, seperti produk pembiayaan pada perbankan syariah masih mencari keuntungan, karena bank masih mempunyai kewajiban seperti membayar gaji karyawan, mengembangkan usahanya. Akan tetapi besaran bunga/riba pada bank syariah tidak sebesar pada bank konvensional. Adapun wujud dalam penerapan sistem syariah islam disini adalah :

1) Setiap manusia bebas melakukan aktivitas selama tidak keluar dari jalur yang dilarang dalam kerangka islam.

2) Adapun pengelolaan kepemilikan yang berhubungan dengan Negara ( State Property) dan kepemilikan individu (Private Property) nampak akan jelas hokum - hukum Baitul Mal serta hukum Mu'amalah, seperti jual beli, gadai ( Rahn) dan sebagainya.

3) Tidak ada potongan bunga yang diterapkan pada system syariah diindonesia ini melainkan bagi hasil kepada nasabah.

4) Lembaga - Lembaga keuangan Syariah yang ada diindonesia sudah menerapkan sistem yangs sesuai dengan ajaran Al'Quran dan As Sunnah

\section{Bank Konvesional Dan Sistem Pembagiannya}

Ketika membicarakan Penerapan pada bank konvensional biasanya kita merujuk pada dua sistem besar yaitu : kapitalisme dan sosialisme. Kapitalisme adalah sistem yang di dasarkan atas pertuk aran sukarela pada pasar bebas, Sebaliknya sosialisme mencoba, mengatasi problem produksi, konsumsi dan distribusi, melalui perencanaan atau komando (Rianto 2017:61). Penerapan konvensional ini boleh dikatakan sebagai sistem yang sudah dipratikan secara meluas dalam sebuah masyarakat. 
Berdasarkan hal tersebut, dapat dikatakan bahwa bahwa penerapan analisis konvensional tersebut dapat ditentukan oleh manusia dalam sebuah masyarakat yang tidak mempunyai kepintaran dan boleh berubah mengikuti ketentuan masyarakat. Sejauh ini kita telah mengetahui perbedaan-perbedaan yang diamentral antara paradigma yang mendasari penerapan system konvensional dengan paradigma yang mendasari penerapan sistem syariah islam. Keduanya tidak mungkin dan tidak akan pemah mungkin untuk dikompromikan, karena masing-masingnya di dasarkan atas pandangan dunia yang berbeda, penerapan sistem konvensional itu sendiri melihat ilmu dengan sesuatu yang sekuler dan sama sekali tidak memasukkan Tuhan Serta tanggung jawab manusia kepada Tuhan di akhirat dalam bangun pemikirannya. Oleh karena itu, dalam penerapan konvensional menjadi bebas nilai (Posivistik). Sementara itu, penerapan sistem bank syariah itu sendiri dibangun atas prinsip-prinsip religius (berorientasi pada kehidupan dunia kini dan disini sekaligus kehidupan akhirat nanti.

\section{Kesimpulan}

Bank pada kontribusi adalah entitas yang melakukan penghimpunan dana dari masyarakat dalam bentuk pembiayaan atau dengan kata lain menjalankan fungsi intermediasi keuangan. Dalam sistem perbankan di Indonesia Ada dua macam sistem perbankan operasional, yaitu bank konvensional dan bank syariah. Sesuai UU No. 21 tahun 2008 tentang Perbankan Syariah, Bank Syariah adalah bank yang menjalankan kegiatan usaha berdasarkan prinsip syariah, atau prinsip hukum islam yang diatur dalam fatwa Majelis Ulama Indonesia seperti prinsip keadilan dan keseimbangan ('adl wa tawazun), kemaslahatan (maslahah) , universalisme (alamiyah), juga tidak mengandung gharar, maysir, riba, zalim dan objek yang haram. Selain itu, UU Perbankan Syariah juga mengamanahkan bank syariah untuk menjalankan fungsi sosial dengan menjalankan fungsi seperti lembaga baitul mal.

Implementasi pengaturan dan pengawasan perbankan syariah dari aspek pelaksanaan prinsip kehati-hatian dan tata kelola yang dilakukan oleh 0JK disetujui pada perbankan konvensional, namun dengan mengatur dan sistem pengawasan yang disesuiakan dengan kekhasan sistem operasi perbankan syariah. Masalah pemenuhan prinsip syariah memang hal unik bank syariah, karena hakikinya bank syariah adalah bank yang menawarkan produk yang sesuai dengan prinsip syariah. Kepatuhan pada prinsip syariah menjadi sangat mendasar karena hal inilah yang menjadi alasan eksistensi bank syariah. Selain itu, setuju pada prinsip syariah dilihat sebagai sisi kekuatan bank syariah. Dengan konsisten pada norma dasar dan prinsip syariah maka kemaslhahatan merupakan sistem kestabilan.

Sistem dan transfer untuk menjamin pemenuhan peraturan syariah yang menjadi isu penting dalam pengaturan bank syariah. Di dalam lembaga ini yang memiliki peran penting adalah Dewan Syariah Nasional (DSN) MUI. Undang - undang No. 21 Tahun 2008 tentang Perbankan Syariah memberikan wewenang kepada MUI yang fungsinya dijalankan oleh organisasinya yaitu DSN-MUI untuk menerbitkan fatwa kesesuaian syariah untuk suatu produk bank. Kemudian Peraturan Bank Indonesia (sekarang POJK) menyetujui produk perbankan syariah hanya boleh ditawarkan kepada masyarakat setelah bank mendapat fatwa dari DSN-MUI dan memperoleh ijin dari OJK. Pada tataran operasional pada setiap bank syariah juga diwajibkan memiliki Dewan Pengawas Syariah (DPS) yang fungsinya ada dua, syariah pertama dan fungsi penasehat (penasehat) kompilasi bank dihadapkan pada pertanyaan mengenai apakah ada aktivitasnya sesuai syariah apa tidak, serta dalam proses melakukan pengembangan produk yang akan dikirim ke DSN untuk mendapatkan fatwa. Selain fun gsi-fungsi, dalam perbankan syariah juga memiliki fungsi audit internal yang berfokus pada bantuan syariah untuk membantu DPS, serta dalam pelaksanaan audit ekstemal yang digunakan bank syariah adalah auditor yang memiliki kualifikasi dan kompetensi di bidang Syariah. 


\section{Saran}

\section{Bagi Bank Syariah}

Secara umum, dari segi profitabilitas dan likuiditas kinerja keuangan Bank syariah lebih baik dibandingkan dengan Bank Konvensional. Akan tetapi, ada beberapa rasio yang lebih rendah dari perbankan konvensional, yaitu rasio permodalan (CAR) dan rasio kualitas asset (NPL). Untuk meningkatkan rasio-rasio tersebut, perbankan syariah perlu memperhatikan hal-hal sebagai berikut:

1) Rasio permodalan. Bank Syariah dapat ditingkatkan kualitasnya dengan penambahan modal. Hal ini dapat dilakukan dengan lebih memperhatikan kebutuhan modal pada setiap ekspansi kredit. Usahakan setiap asset yang berisiko tersebut menghasilkan pendapatan, sehinggga tidak perlu menekan permodalan.

2) Rasio Kualitas Asset dapat ditingkatkan kualitasnya dengan lebih berhati-hati dalam pemberian kredit terhadap nasabah untuk mengurangi jumlah kredit yang macet dan bermasalah.

\section{Bagi Bank Konvensional}

Penelitian ini menyimpulkan bahwa kinerja Bank Syariah secara umum dari segi penyaluran kredit dan profitabilitas lebih baik dibandingkan Bank Konvensional.

\section{Daftar Pustaka}

Abdullah Amrin, (2009). Bisnis Ekonomi Asuransi dan Keuangan Syariah, Jakarta: PT Raja Grafindo Persada.

Adiwarman A. Karim, (2011). Ekonomi Makro Islam, Jakarta: PT Raja Grafindo.

Agnes Sawir, (2005) Analisis Kinerja Keuangan dan Perencanaan Keuangan Perusahaan, Jakarta: PT Gramedia Pustaka Utama.

Badriyah Harun, (2010). Penyelesaian Sengketa Kredit Bermasalah Solusi Hukum, Yogyakarta: Pustaka Yustisia.

Bambang Sunggono, (2007). Metode Penelitian Hukum, Jakarta: PT Raja Grafindo.

Hendy Herijanto, (2013). Selamatkan Perbankan, Jakarta: PT Mizan Publikasi,

Http:katakarim.blogspot.com/2010/03/manajemenresiko.perbankan.html

Iswi Haryani, (2010). Restrukturisasi dan Penghapusan Pembiayaan Macet, Jakarta: Media Komputindo.

M Solly Lubis, (1994). Filsafat Ilmu dan Penelitian, Bandung: Mandar Madju,

Nawawi, (1995). Metode Penelitian Bidan Sosial. Yogyakarta: Gadjah Mada University Press.

Peraturan Bank indonesia Nomor 6/24/PBI/2004

Ronny Kountur, (2007). Metode Penelitian, Jakarta: PPM.

Snelbecker, (2006). Metodologi Penelitian Kualitatif. Bandung:

Soerjono Soekamto dan Sri Mahmudji, (1994). Penelitian Hukum Normatif Suatu Tinjauan Singkat, Jakarta: Raja. Grafindo Persada.

Totok Budi Santoso dan sigit Triadani, (2014). Bank dan Lembaga Keuangan, Jakarta: Salemba Empat. 